\title{
Variation in Crossability among Rhododendron japonicum f. flavum Plants as Pollen Parents when Crossed with Evergreen Species, $R$. eriocarpum
}

\author{
Akihide Okamoto*, Hiroshi Ikeda and Kenichi Suto** \\ Department of Vegetable and Flower Research, National Agricultural Research Center for Kyushu Okinawa Region, \\ Kurume 839-8503, Japan
}

\begin{abstract}
An attempt was made to obtain the paternal parental stock to hybridize evergreen azaleas (seed parent) with Rhododendron japonicum (A. Gray) J. V. Suringar f. flavum Nakai (pollen parent). To examine the variation in hybridization barriers and crossability, pollen from nine accessions of $R$. japonicum f. flavum were used to pollinate one plant of $R$. eriocarpum (Hayata) Nakai. Significant differences among R. japonicum f. flavum accessions appeared in fertilization rate, mature seed numbers per capsule, albino rate, survival rate, and the crossability. Pollination with pollen of $R$. japonicum $\mathrm{f}$. flavum accessions 27026136 and 27026139 yielded a relatively large number of viable seedlings per pollinated flower as compared to the others. Our results suggest that it is important to select highly crossable $R$. japonicum $\mathrm{f}$. flavum plants as the pollen parent to obtain true hybrids.
\end{abstract}

Key Words: crossability, evergreen azalea, hybridization barrier, Rhododendron japonicum.

\section{Introduction}

To produce yellow-flowered hybrids of evergreen azaleas, yellow-flowered deciduous species, Rhododendron japonicum (A. Gray) J. V. Suringar f. flavum Nakai as a pollen parent was crossed with evergreen azaleas. In this intersubgeneric hybridization, however, pre- and post-fertilization barriers existed so that viable seedlings were rarely obtained (Akabane et al., 1971; Noguchi, 1932). Several attempts have been made for the purpose of obtaining the viable hybrid plants, including a threeway crossing (Ureshino et al., 1998) and interploidy crossing (Sakai et al., 2001). Major emphasis of these studies has been to choose the right maternal plants among evergreen azaleas. So far, a few works using some $R$. japonicum f. flavum plants as a pollen parent were performed (Ureshino et al., 2000; Ureshino et al., 1998), but there are no reports that evaluated the crossability of individual plants of $R$. japonicum $\mathrm{f}$. flavum.

This work was carried out to examine the variation in the hybridization barriers and crossability among $R$. japonicum f. flavum accessions as pollen parents when crossed with the evergreen species, $R$. eriocarpum (Hayata) Nakai. An attempt was made to obtain a functional paternal parental stock.

Received; June 1, 2005. Accepted; September 28, 2005.

* Corresponding author (E-mail: akioka@affrc.go.jp).

** Present address: Agriculture, Forestry and Fisheries Technical Information Society.

\section{Materials and Methods}

Nine accessions of $R$. japonicum $\mathrm{f}$. flavum that were used as the pollen parent, were collected as seeds from Seidagawa, Oita and planted at Department of Vegetable and Flower Research, National Agricultural Research Center for Kyushu Okinawa Region. $R$. eriocarpum accession 27024528 which showed relatively crossable with $R$. japonicum f. flavum (Okamoto and Suto, 2004) was used as the seed parent. This plant endogenous to Yakushima (Kagoshima Prefecture), was donated by an azalea grower.

Anthers were collected from flower buds at the beginning of anthesis and preserved from the middle of April to late May at $4^{\circ} \mathrm{C}$ in the dark. Flower buds on the maternal parent were emasculated at the beginning of anthesis and mucus-covered stigma were handpollinated. Ten days after pollination, three pistils were collected from the seed plant, fixed in FAA (formalin : $70 \%$ ethanol : acetic acid $=1: 18: 1(\mathrm{v} / \mathrm{v} / \mathrm{v})$ ) for $24 \mathrm{~h}$, after which they were transferred to $70 \%$ ethanol. Microscopic observations of the pollen tubes that penetrated into the ovules were made according to the method of Okamoto and Suto (2004). Five capsules were collected in October from each cross and the number of seeds per capsule was counted. More than 300 seeds from each cross were planted in November and tested in triplicate in different years. The methods of seeding and growing of the hybrid plants were those of Okamoto and Suto (2004). Germinated seedlings were counted once a week from December to February and the color of cotyledons noted. Two years after sowing, 
the number of viable seedlings for each cross was recorded.

Numerical comparisons were carried out by analysis of variance (when the variable was normal distributed) and Kruskal-Wallis analysis (when the variable was not normally). Tukey's Honestly Significant Different test was used to compare means of different paternal classes.

\section{Results}

A significant differences among the experimental results obtained from the nine pollen parents (Table 1 and 2) show that the percentage of ovules penetrated by the pollen tubes (fertilization rate) varied from $30.4 \%$ to $61.1 \%(P<0.001)$. Accession 27026138 had the significantly higher percentage than accessions 27026136, 27026143, and 27026144. All nine crosses produced capsules with set exceeding $90 \%$ (data not shown); No statistically significant difference was found among the pollen parents. The number of mature seeds per capsule varied from 301.4 to 557.4. This difference was significant at $P<0.001$. More seeds were produced when the maternal parent was pollinated by accessions 27026137 and 27026138 than by 27026136 and 27026144. The germination rate varied from $9.3 \%$ to $37.6 \%$, but no significant difference existed in the pollen parents $(P=0.093)$. The cotyledon colors of the hybrid seedlings segregated into green, yellow-green, palegreen, and white. Albino seedling made up from 5.5\% to $18.5 \%$ of the population; the difference being significant at $P<0.01$. Accessions 27026139, 27026143, and 27026144 produced fewer albino progenies compared to 27026136 and 27026138 . The variability of the green, yellow-green, and pale-green cotyledons was so large that no statistically significant difference existed $(P=0.068,0.225,0.442$, respectively). The percentage of viable seedlings/the germinating seedlings excluding the albinos (survival rate) varied from $0 \%$ to $20.8 \%(P<0.05)$. The number of viable seedlings per pollinated flower (crossability) ranged from 0 and 7.3 $(P<0.01)$. There were a few viable seedlings so that no statistical analysis could be made to compare means of different paternal classes. But it was clear that accessions

Table 1. Significant differences in hybridization barriers and crossability between a Rhododendron eriocarpum as a seed parent and nine $R$. japonicum f. flavum accessions as pollen parents.

\begin{tabular}{|c|c|c|c|}
\hline Character & Method of statistical test & F ratio & $\chi^{2}$ \\
\hline Fertilization rate ${ }^{z}$ & Analysis of variance & $6.276^{* * * v}$ & - \\
\hline Number of mature seeds per capsule ${ }^{y}$ & Analysis of variance & $4.749 * * *$ & - \\
\hline Germination rate & Analysis of variance & $2.305 \mathrm{NS}$ & - \\
\hline Green seedling rate & Kruskal-wallis analysis & - & $14.569 \mathrm{NS}$ \\
\hline Yellow-green seedling rate & Analysis of variance & $1.555 \mathrm{NS}$ & - \\
\hline Pale-green seedling rate & Analysis of variance & $1.058 \mathrm{NS}$ & - \\
\hline Albino seedling rate & Analysis of variance & $5.818^{* *}$ & - \\
\hline Survival rate ${ }^{x}$ & Kruskal-wallis analysis & - & $19.588^{*}$ \\
\hline Crossing ability ${ }^{\mathrm{w}}$ & Kruskal-wallis analysis & - & $25.130 * *$ \\
\hline
\end{tabular}

${ }^{\mathrm{z}}$ Ovule penetrated by pollen tubes.

y Logarithmic transformation.

${ }^{\mathrm{x}}$ Viable seedlings/germinating seedlings excluding albinos.

${ }^{\mathrm{w}}$ Number of viable seedlings per pollinated flower.

v*,**,*** and NS indicate significance at $P=0.05,0.01,0.001$ and non-significance, respectively.

Table 2. Fertilization rate, number of mature seeds per capsule, germination rate, cotyledon colors of seedlings, survival rate and crossability between a Rhododendron eriocarpum as a seed parent and nine $R$. japonicum f. flavum accessions as pollen parents.

\begin{tabular}{|c|c|c|c|c|c|c|c|c|c|}
\hline \multirow{2}{*}{$\begin{array}{l}\text { Pollen parent } \\
\text { (accession no.) }\end{array}$} & \multirow{2}{*}{$\begin{array}{l}\text { Fertilization }^{2} \\
\text { rate }(\%)\end{array}$} & \multirow{2}{*}{$\begin{array}{l}\text { Number of mature seeds } \\
\text { per capsule }\end{array}$} & \multirow{2}{*}{$\begin{array}{l}\text { Germination } \\
\text { rate }(\%)\end{array}$} & \multicolumn{4}{|c|}{$\%$ of seedlings ${ }^{y}$} & \multirow{2}{*}{$\begin{array}{c}\text { Survival rate } \\
(\%)\end{array}$} & \multirow{2}{*}{ Crossability } \\
\hline & & & & G & YG & PG & W & & \\
\hline 27026136 & $39.1 b^{x}$ & $333.4 \mathrm{bc}$ & 24.9 & 18.3 & 27.2 & 36.8 & $17.7 \mathrm{a}$ & 20.8 & 7.3 \\
\hline 27026137 & $49.9 \mathrm{ab}$ & $538.0 \mathrm{a}$ & 10.3 & 4.0 & 27.2 & 53.8 & $15.0 \mathrm{ab}$ & 0 & 0 \\
\hline 27026138 & $61.1 \mathrm{a}$ & $557.4 \mathrm{a}$ & 31.0 & 2.8 & 25.4 & 53.3 & $18.5 \mathrm{a}$ & 0 & 0 \\
\hline 27026139 & $54.7 \mathrm{ab}$ & $413.8 \mathrm{abc}$ & 16.8 & 23.9 & 32.6 & 36.4 & $7.1 \mathrm{~b}$ & 10.7 & 5.6 \\
\hline 27026140 & $48.3 \mathrm{abc}$ & $492.0 \mathrm{ab}$ & 9.3 & 6.8 & 22.2 & 55.1 & $16.0 \mathrm{ab}$ & 0 & 0 \\
\hline 27026141 & $53.9 \mathrm{ab}$ & $380.6 \mathrm{abc}$ & 26.1 & 9.0 & 36.8 & 44.8 & $9.4 \mathrm{ab}$ & 5.4 & 0.5 \\
\hline 27026142 & $44.5 \mathrm{abc}$ & $361.0 \mathrm{abc}$ & 37.6 & 3.6 & 25.1 & 57.1 & $14.2 \mathrm{ab}$ & 0.8 & 0.7 \\
\hline 27026143 & $41.3 \mathrm{bc}$ & $391.0 \mathrm{abc}$ & 14.6 & 13.4 & 35.2 & 46.0 & $5.5 \mathrm{~b}$ & 0 & 0 \\
\hline 27026144 & $30.4 \mathrm{c}$ & $301.4 \mathrm{c}$ & 22.9 & 13.6 & 45.9 & 33.1 & $7.5 \mathrm{~b}$ & 1.9 & 0.9 \\
\hline
\end{tabular}

\footnotetext{
${ }^{z}$ Refer to Table1.

${ }^{y}$ Color of cotyledons: G, green; YG, yellow-green; PG, pale-green; and W, white.

${ }^{x}$ Same letters are not significantly different $(P<0.05)$ based on a Tukey's means comparison.
} 
27026136 and 27026139 exhibited greater crossability than the rest.

\section{Discussion}

The evaluation of the crossability between evergreen azaleas and $R$. japonicum f. flavum, and the understanding of the mechanisms governing seedling formation, may increase the frequency of obtaining yellow-flowered evergreen azalea through the normal breeding process. Previously, pollen-pistil/style incompatibility was observed in the crosses that used $R$. japonicum f. flavum as the seed parent (Creech, 1955; Ureshino et al., 2000). Thus, it seems that to obtain hybrid plants, only $R$. japonicum f. flavum should serve as the pollen parent. In this experiment, the nine accessions of $R$. japonicum f. flavum differed significantly in the fertilization rate, mature seed numbers, the albino rate, the survival rate, and crossability, indicating that these factors are influenced by the choice of the pollen parent.

That accessions 27026136 and 27026139 produced a relatively large number of viable seedlings per pollinated flower indicate that they overcame some hybridization barriers. However, the crossability and some hybridization barriers were not normal distributed, so no statistical analysis was performed to determine which primarily governs the production of viable progenies.

Our experiment indicates that a possibility exists to increase the number of viable seedlings by choosing the right paternal parent. Guéritaine et al. (2003) stated that the most efficient pollen donors to fertilize one of the cultivar were the least able to fertilize the others in interspecific hybridization between oilseed rape and wild radish. In our prior experiments (Okamoto and Suto, 2002, 2004), we did not use the embryo rescue and a ovule culture, but found many cross combinations that produce the viable seedlings. We presumed this success was due to the use of pollen of $R$. japonicum $\mathrm{f}$. flavum accession 27026136. Therefore, $R$. japonicum $\mathrm{f}$. flavum accessions 27026136 and 27026139 might be the efficient pollen donors to advance the progress of obtaining yellow-flowered evergreen azaleas.

\section{Literature Cited}

Akabane, M., A. Yamanaka, D. Takashima, T. Nakatsue and Y. Nakamura. 1971. Cross fertility and growth of hybrid plants in Rhododendron. Bull. Tochigi Pref. Agri. Expt. Stn. 15: 95-102 (In Japanese).

Creech, J. L. 1955. An embryological study in the Rhododendron subgenus Anthodendron Endl.. Bot. Gaz. 116: 234-243.

Guéritaine, G., J. F. Bonavent and H. Darmency. 2003. Variation of prezygotic barriers in the interspecific hybridization between oilseed rape and wild radish. Euphytica 130: 349-353.

Noguchi, Y. 1932. Studies on the species crosses of Japanese Rhododendron. 1. On the crossability between various species and the cotyledon color of $\mathrm{F}_{1}$ seedlings. Jap. J. Bot. 6: 103-126.

Okamoto, A. and K. Suto. 2002. Intersubgeneric hybridization between Kurume azalea and Rhododendron japonicum $\mathrm{f}$. flavum. J. Japan. Soc. Hort. Sci. 71 (Suppl. 2): 179 (In Japanese).

Okamoto, A. and K. Suto. 2004. Cross incompatibility between Rhododendron sect. Tsutsusi species and Rhododendron japonicum (A. Gray) J. V. Suringar f. flavum Nakai. J. Japan. Soc. Hort. Sci. 73: 453-459.

Sakai, K., K. Ureshino, A. Michishita, Y. Ozaki, M. Akabane and I. Miyajima. 2001. Effectiveness of interploid crossings for obtaining green seedlings from evergreen azaleas $\times$ Rhododendron japonicum f. flavum. J. Japan. Soc. Hort. Sci. 70 (Suppl. 2): 411 (In Japanese).

Ureshino, K., M. Kawai and I. Miyajima. 2000. Factors of intersectional unilateral cross incompatibility between several evergreen azalea species and Rhododendron japonicum f.flavum. J. Japan. Soc. Hort. Sci. 69: 261-265.

Ureshino, K., I. Miyajima and M. Akabane. 1998. Effectiveness of three-way crossing for the breeding of yellow-flowered evergreen azalea. Euphytica 140: 113-118.

\section{花粉親に用いたキレンゲッツジにおける \\ 常緑性ツッジ野生種マルバサッキとの 交雑能力の個体間差異}

\author{
岡本章秀・池田 廣・須藤憲一* \\ 農業・生物系特定産業技術研究機構 九州沖縄農業研究 \\ センター野菜花き研究部 839-8503 久留米市御井町
}

常緑性ツッジ（種子親）と，キレンゲッッジ（花粉親） との交雑について, 花粉親として優れる交雑母本の選定 を試久た。キンゲッッジ個体間の各交雑阻害原因沶よび 交雑能力の変異を調査するため, キレンゲッッジ 9 個体 の花粉を供試し，マルバサッキ 1 個体に交雑した，その 結果, 受精率, 種子数/果, 白子率, 生存率抢よび交雑 能力について，キレンゲッッジ個体間に有意差が認めら れた。 キレンゲッッジ遺伝資源番号 27026136 および 27026139 を用いた交雑では他を用いた場合に比べて, 交 雑花当たりの生存可能な実生数が多かった. 以上から, 花粉親に用いるキレンゲッッジ個体を選定することは, 常緑性ツッジ xキレンゲッッジの実生獲得において重要 であることが示唆された.

* 現在 : 農林水産技術情報協会. 